\title{
Importance of Acorus calamus in Rural Livelihood Security of District Ganderbal in Kashmir Valley, India
}

\author{
G. M. Bhat ${ }^{1 *}$, Rayees A. Bhat ${ }^{1}$, M. A. Islam ${ }^{1}$, T. A. Rather ${ }^{1}$, \\ F. A. Shahkhan ${ }^{2}$, Huzaifa Majeed ${ }^{1}$ and Nida Rafiq ${ }^{1}$ \\ ${ }^{1}$ Faculty of Forestry, Sher-e-Kashmir University of Agricultural Sciences \& Technology of \\ Kashmir, Benihama Ganderbal Campus (UT of J\&K), India \\ ${ }^{2}$ High Mountain Arid Agriculture Research Institute, Stakna, SKUAST-K, Leh, India \\ *Corresponding author
}

\section{A B S T R A C T}

Acorus calamus is perennial medicinal herb is commonly growing on the banks of streams and in dampy marshy places in Kashmir valley. In Ayurvedic medicine Acorus calamus is an important herb and is valued as a "rejuvenator" for the brain and nervous system and as a remedy for digestive disorders. The rhizome of Acorus calamus is used for various medicinal purpose mainly appetite, fever, stomach cramps, tooth ache. The present study

\section{Keywords}

Acorus calamus, Rural Livelihood, Ayurvedic medicine

Article Info

Accepted:

10 September 2020

Available Online:

10 October 2020 investigated the collection, consumption and sale of Acorus calamus and its contribution to household income and employment besides analyzing the factors influencing the Acorus calamus exploitation in the locality using Ex-Post-Facto Research Design. Purposive sampling technique was employed in the area of study (district Ganderbal). The livelihood security from Acorus calamus depends on multitude of household socioeconomic and biophysical factors like education, size of family, size of land holding, herd size, main occupation, family labour and gross annual income, Of the all off-farm and on-farm income sources The total average collection/household/annum of Acorus calamus was $67.3 \mathrm{~kg}$, from which total average $61.7 \mathrm{kgs}$, were processed, average $5.1 \mathrm{kgs}$ were consumed by per family house hold and it provided total average employment of 68.66 man days to the single sample household The Acorus based cottage industry was found the $5^{\text {th }}$ major constituent of household income employment in the study site. The household characteristics influencing the Acorus calamus livelihood in the locality averaged for the sample population indicated the respondents $(74.33 \%)$ were old aged followed by middle $(24.33 \%)$ age groups respectively. The mean age was 72.16 , among these $(26.66 \%)$ were illiterate followed by below primary $(20.00 \%)$, primary $(18.33 \%)$ The mean score of education was 2.1 which indicated that low literacy dominates in the surveyed population. The number of large farmers was nil $(0.00 \%)$ with average score of landholding as 1.45 which indicated the prevalence of marginal landholders among the sample households.

\section{Introduction}

India is one of the 12 mega biodiversity centers of the world with two major hot spots of endemic species and 49, 000 plant species reported in 16 agro-climatic zones of the country. There are about 15,000 to 20,000 plant species reported to have medicinal value 
with 30 per cent considered as endemic to the country. Among these 7, 000-8, 000 are reported to be used in unregulated informal systems of medicine and 1, 200-2, 000 in the regulated AYUSH (Qazi, 2003). In India it is estimated that 275 million poor rural people are depend on NTFPs for at least part of their subsistence and cash livelihoods (Pandey et al., 2016). This provides $50 \%$ of household income for 20 to $30 \%$ of rural population particularly for tribal. Around 50\% of forest revenues and $70 \%$ of forest based export income of the country comes from NTFPs. Thus it can be depicted that NTFPs form one of the mainstays of income and sustenance for many tribal communities (Ibrahim et al., 2016).The collection of NTFPs by rural dwellers was primarily for meeting their subsistence needs. Over time, these NTFPs acquired commercial value resulting from huge trade transactions and income levels due to rising demand (Bharathkumar et al., 2011).

Kashmir harbours an incredible diversity of NTFPs which satisfy the social, economic, cultural, religious, ethical, traditional, spiritual, ecological and political aspirations of the human being from time immemorial. The NTFPs are used by the local communities to meet their daily livelihood needs in terms of foods, fuel, fodder and browse, mulch and compost, shelter, housing and fencing materials, utensils, ornamental and decorative items, musical instruments, furniture, fibre, medicines, dyes, thatch, brushes and brooms, religious and aesthetic goods, animal products, abiotic materials etc. Despite their huge potential, the contribution of NTFP's to local economy and employment is still insignificant. An effective management of the entire NTFPs exploitation is a key factor for successful commercialization of NTFPs in the global market which will enormously boost employment and income generation opportunities and improve the livelihoods of local people in the state.
NTFPs are significant especially for poor, because they are available at low cost on common property lands. They are used by people because they have less alternative access to food and income. In a country like. India, which has more than half of its population in rural areas and a large tribal population reliant on forest produce for their sustenance, The range of livelihood strategies includes both off-farm and land-based livelihood strategies, including the use of nontimber forest products (NTFPs) both for household consumption and for sale.

The contribution made by NTFPs to household income has been found, in certain cases, to be considerable and comparable to other income sources (Sapkota and Odén, 2008). World Bank (2001) estimates that one out of four of the world's poor depend directly or indirectly on forests for their livelihood. During the last decade, there has been a dramatic increase in interest and research of NTFPs (Shillington, 2002). Among different NTFPs one Ocimum basilicum is a important herb which grows in wetlands and is collected locally by the people residing near its natural habitat for its ethnomedicinal use and for its sale in open market because of its medicinal properties. Acorus calamus is a perennial plant with creeping and extensively branched, aromatic rhizome, cylindrical, up to $2.5 \mathrm{~cm}$ thick, purplish- brown to light brown externally and white internally. This perennial herb is common on the banks of streams and in damp marshy places. In Ayurvedic medicine Acorus calamus is an important herb and is valued as a "rejuvenator" for the brain and nervous system and as a remedy for digestive disorders. The rhizome of Acorus calamus is used for various medicinal purpose mainly appetite, fever, stomach cramps, tooth ache and cholic (Divya et al., 2011). Keeping the significance of acorus in view the present study was undertaken in Ganderbal district of 
Kashmir to assess the household livelihood contribution of Acorus calamus L. based cottage industry.

\section{Materials and Methods}

The study was conducted in the central district Ganderbal of Kashmir valley. The present study investigated the collection, consumption and sale of Acorus calamus and its contribution to household income and employment besides analyzing the factors influencing the Acorus calmus exploitation in the locality using Ex-Post-Facto Research Design. Purposive sampling technique was employed in the distric viz., Ganderbal to select the villages and households in order to reach target sample quickly. Purposive sampling technique was employed in the district Ganderbal to select the villages and households in order to reach target sample quickly. The first stage was the selection of villages, 6 villages (Peerpora, Tulmulla, Rabitar, Darkpura, Sindbal and Shalbug) from district Ganderbal were selected. which were near to wetlands. The second stage was selection of households.

A sample of 60 households was drawn from the sample villages having 5 percent sampling intensity using simple random sampling technique for the field study. The primary data was collected by the personal interviews of the respondents through a well-structured pre-tested interview schedule at household level Interview schedule for household survey was prepared on the basis of literature referred, reconnaissance survey of the study area, and discussion with local people and consultation with the experts. Quasiparticipant observation method was used to record the data on the basis of personal observation and interaction with the respondents. This technique helped to have first hand on-the-scenes contact with the respondents, examine the behavior in natural situation and study the situation based features of conduct. The facts were gathered by assuming several roles as participant, interviewer, stranger or listener in various social, cultural, religious or political activities.

\section{Household livelihood contribution of Acorus calamus}

The questions asked through interview schedule included data on socioeconomic characteristics of growers, collection per anum, consumption/anum, sale/anum, quantity marketed, income generation, various sources of households' income and economic contribution of Acorus calamus.

The socioeconomic variables of the Farmers/ growers included age, education, social participation, family composition, land holding, livestock possession, housing status, subsequent occupation, wealth status and annual income and the variables were measured using "Socio-economic status scale" of Venkataramaiah (1990) after some modification. The observations extracted from survey were used to triangulate and validate the data gathered through household survey, interpret the results and draw inferences.

\section{Statistical analysis}

\section{Frequency (f)}

The frequency $(f)$ was used to denote how frequently a response or character appears in a class or category.

\section{Percentage (\%)}

Percentages (\%) were used in data presentation to simplify and reduce the numbers in the standard form with base equal to 100 . 


\section{$\operatorname{Mean}(\bar{X})$}

The mean was computed by the formula:

$\overline{\mathrm{X}}=\frac{\sum \mathrm{f} \cdot \mathrm{x}}{N}$

Where,

$\overline{\mathrm{X}}=$ mean of the scores

$\sum=$ summation

$f=$ frequency of the class

$x=$ class value or midpoint of the class interval

$N=$ number of observations

\section{Standard deviation}

Standard deviation was defined as the square root of the mean of the squared deviations of individual's values from their mean and it is denoted

\section{Results and Discussion}

Acorus calamus collection, consumption and marketing in the sample households $(\mathrm{N}=60)$

The findings pertaining to household collection, consumption and marketing from the Acorus calamus in district Ganderbal among sampled households $(\mathrm{N}=60)$ illustrated that the total collection of Acorus calamus was $4038.00 \mathrm{~kg}$, of which average collection/household/annum was $67.3 \mathrm{~kg}$. the total gross income generated from Acorus calamus among the sample households was Rs.129120.00 of which average income/household/annum was Rs.2152.00, the total net income generated was Rs.96120.00 of which average income/household/annum was Rs.1602.00 and the total average employment was 68.66 man days by the single sample household.

The data presented in the Table 2 reveals that maximum gender contribution in collection of Acorus calamus were men and women (35\%) followed by men and children $(20 \%)$ and men $(16.67 \%)$ revealed that average gross annual income consisted of all off-farm and on-farm sources among the surveyed population was Rs.47992.63 (Table 3) Acorus based cottage industry was found to be the $5^{\text {th }}$ major constituent of household income employment in the study site. A perusal of Table 4 revealed that most of the respondents (74.33\%) were old aged followed by middle $(24.33 \%)$ age groups respectively who were involved in collection trade. The mean score of education was 2.1 which indicated that low literacy dominates in the surveyed population. The mean score of family size was 1.61 which indicated the prevalence of large sized families in the surveyed population.

Table.1 Acorus calamus collection, consumption and marketing

\begin{tabular}{|l|l|l|}
\hline Particulars & Total & Average \\
\hline Collection/annum (kg) & 4038.00 & 67.3 \\
\hline Processing/annum (kg) & 3702.00 & 61.7 \\
\hline Consumption/annum (kg) & 306.00 & 5.1 \\
\hline Sale/annum (kg) & 3228.00 & 53.8 \\
\hline Gross income (Rs) & 129120.00 & 2152.00 \\
\hline Transportation/other costs (Rs) & 33000.00 & 550.00 \\
\hline Net income (Rs) & 96120.00 & 1602.00 \\
\hline Employment (mandays) & 41196.00 & 68.66 \\
\hline
\end{tabular}


Table.2 Involvement of family members in Acorus calamus L. collection

\begin{tabular}{|l|c|c|}
\hline Involvement of family members & Number of households & Percentage \\
\hline Men & 10.00 & 16.67 \\
\hline Women & 3.00 & 5.00 \\
\hline Children & 0.00 & 0.00 \\
\hline Men and women & 21.00 & 35.00 \\
\hline Men and children & 12.00 & 20.00 \\
\hline Women and Children & 8.00 & 13.00 \\
\hline All members & 6.00 & 10.00 \\
\hline Total & 60 & 100.00 \\
\hline
\end{tabular}

Table.3 Contribution of Acorus calamus to household income and employment $(\mathrm{N}=60)$

\begin{tabular}{|l|c|c|}
\hline Livelihood source & $\begin{array}{c}\text { Income } \\
\text { (Rs/HH/annum) }\end{array}$ & $\begin{array}{c}\text { Employment (Man- } \\
\text { days/HH/annum) }\end{array}$ \\
\hline Acorus based cottage industry & $2152.00(4.48)$ & $68.66(24.57)$ \\
\hline Agriculture & $20883.55(43.41)$ & $82.50(29.52)$ \\
\hline Livestock rearing & $17500.00(36.46)$ & $80.50(28.80)$ \\
\hline Wage labour & $450.75(0.93)$ & $4.50(1.61)$ \\
\hline Herbal medicine & $3040.00(6.33)$ & $25.50(9.12)$ \\
\hline Business & $1565.33(3.26)$ & $8.25(2.95)$ \\
\hline Service & $2291(4.77)$ & $9.36(3.34)$ \\
\hline Other activities & $110(0.22)$ & $0.15(0.05)$ \\
\hline Total & $\mathbf{4 7 9 9 2 . 6 3 ( 9 9 . 9 6 )}$ & $\mathbf{2 7 9 . 4 2}(\mathbf{9 9 . 9 6 )}$ \\
\hline
\end{tabular}

Figures in parentheses show percentages

Table.4 Age, education and family size of the sample households $(\mathrm{N}=60)$

\begin{tabular}{|c|c|c|c|c|c|}
\hline \multicolumn{2}{|l|}{ Age } & \multicolumn{2}{|l|}{ Education } & \multicolumn{2}{|l|}{ Family size } \\
\hline Category & Household & Category & Household & Category & Household \\
\hline $\begin{array}{l}\text { Young (up to } \\
30 \text { years) }\end{array}$ & - & Illiterate & $16(26.66)$ & $\begin{array}{l}\text { Small (up to } 5 \\
\text { members) }\end{array}$ & $20(33.33)$ \\
\hline $\begin{array}{l}\text { Middle (31 to } \\
50 \text { years) }\end{array}$ & $15(24.33)$ & Below primary & $12(20.00)$ & $\begin{array}{l}\text { Large }(>\quad 5 \\
\text { members })\end{array}$ & $40(66.66)$ \\
\hline $\begin{array}{l}\text { Old } \\
\text { years })\end{array} \quad \begin{array}{ll}> & \end{array}$ & $45(74.33)$ & Primary & $11(18.33)$ & - & - \\
\hline- & - & Middle & $8(13.33)$ & - & - \\
\hline- & - & High school & $6(10.00)$ & - & - \\
\hline- & - & Intermediate & $5(8.33)$ & - & - \\
\hline- & - & $\begin{array}{l}\text { Graduate } \quad \& \\
\text { above }\end{array}$ & $2(3.33)$ & - & - \\
\hline \multicolumn{2}{|c|}{$X \pm$ S.E. $=72.16 \pm 1.07$} & \multicolumn{2}{|c|}{$\mathrm{X} \pm$ S.E. $=2.1 \pm 0.23$} & \multicolumn{2}{|c|}{$X \pm$ S.E. $=1.61 \pm 0.49$} \\
\hline
\end{tabular}

Figures in the parentheses show percentages 
Table.5 Size of land holding and herd size in the sample households $(\mathrm{N}=60)$

\begin{tabular}{|l|c|c|c|}
\hline \multicolumn{2}{|c|}{ Size of land holding } & \multicolumn{2}{c|}{ Herd size } \\
\hline Category & Household & Category & Household \\
\hline Landless & $4(6.66)$ & No livestock & $5(8.33)$ \\
\hline Marginal (<1.00 ha) & $45(75.00)$ & Up to 5 livestock & $14(23.33)$ \\
\hline Small (1.01-2.00 ha) & $8(13.33)$ & 6 to 10 livestock & $31(51.66)$ \\
\hline Medium (2.01-4.00 ha) & $3(5.00)$ & $>10$ livestock & $10(16.66)$ \\
\hline Large (> 4.00 ha) & 0 & - & - \\
\hline X $\mathbf{\text { S.E. } = \mathbf { 1 . 4 5 } \pm \mathbf { 0 . 7 6 }}$ & & X \pm S.E. $=1.76 \pm 0.10$ \\
\hline
\end{tabular}

Figures in the parentheses show percentage

Table.6 Main occupation, family labour and gross annual income in the sample households $(\mathrm{N}=60)$

\begin{tabular}{|c|c|c|c|c|c|}
\hline \multicolumn{2}{|c|}{ Main occupation } & \multicolumn{2}{|c|}{ Family labour } & \multicolumn{2}{|l|}{ Gross annual income } \\
\hline Category & Household & Category & Household & Category & Household \\
\hline Wage labour & $13(21.66)$ & 1 & $13(21.66)$ & $\begin{array}{l}\text { Very low income (Up } \\
\text { to Rs. } 30000 / \text { annum) }\end{array}$ & $15(25.00)$ \\
\hline $\begin{array}{l}\text { Caste } \\
\text { occupation }\end{array}$ & $7(11.66)$ & 2 & $16(26.66)$ & $\begin{array}{lr}\text { Low } & \text { income } \\
\text { (Rs.30001 } & \text { to } \\
\text { 60000/annum) }\end{array}$ & $32(53.33)$ \\
\hline Cultivation & $26(43.33)$ & 3 & $23(38.33)$ & $\begin{array}{l}\text { Medium income } \\
\text { (Rs.60001 to } \\
\text { Rs.90000/annum) }\end{array}$ & $8(13.33)$ \\
\hline Business & $09(15.00)$ & $>3$ & $8(13.33)$ & $\begin{array}{l}\text { High income } \\
\text { (>Rs.90000/annum) }\end{array}$ & $5(8.33)$ \\
\hline Service & $3(5.00)$ & & & - & - \\
\hline Any other & $2(3.33)$ & & & - & - \\
\hline \multicolumn{2}{|c|}{$X \pm$ S.E. $=3.15 \pm 1.14$} & \multicolumn{2}{|c|}{$\mathrm{X} \pm$ S.E. $=2.43 \pm 0.12$} & \multicolumn{2}{|c|}{$X \pm$ S.E. $=47992.63 \pm 4304.672$} \\
\hline
\end{tabular}

Figures in the parentheses show percentages

Table.7 Proximity to wetland, frequency of wetland visits and extent of agro forestry/homestead forestry of the sample households $(\mathrm{N}=60)$

\begin{tabular}{|l|l|l|l|l|l|}
\hline \multicolumn{2}{|l|}{ Proximity to wetlands } & \multicolumn{2}{l|}{ Frequency of wetlands visits } & \multicolumn{2}{l|}{ Forestry resource possession } \\
\hline Category & Household & Category & Household & Category & Household \\
\hline $\mathbf{5} \mathbf{5} \mathbf{~ k m}$ & $25(41.66)$ & Very frequently & $7(11.66)$ & $<0.10$ ha & $30(5.00)$ \\
\hline $\mathbf{5 - 1 0} \mathbf{~ k m}$ & $20(33.33)$ & Frequently & $25(41.66)$ & $0.11-0.20$ ha & $14(23.33)$ \\
\hline $\mathbf{1 0 - 1 5} \mathbf{~ k m}$ & $15(25.00)$ & Occasionally & $18(30.00)$ & $0.21-0.30$ ha & $10(16.66)$ \\
\hline $\mathbf{> 1 5} \mathbf{~ k m}$ & $0(0.00)$ & Never & $10(16.66)$ & $>0.30$ ha & $6(10.00)$ \\
\hline $\mathbf{X} \pm$ S.E. $=\mathbf{1 . 9 4} \pm \mathbf{0 . 7 0}$ & X \pm S.E. $=1.96 \pm 1.13$ & X \pm S.E. $=1.23 \pm 0.67$ \\
\hline
\end{tabular}

Figures in the parentheses show percentage 
Plate.1 Collection of rhizomes of Acorus calamus L. by local people for livelihood in a village of Ganderbal district
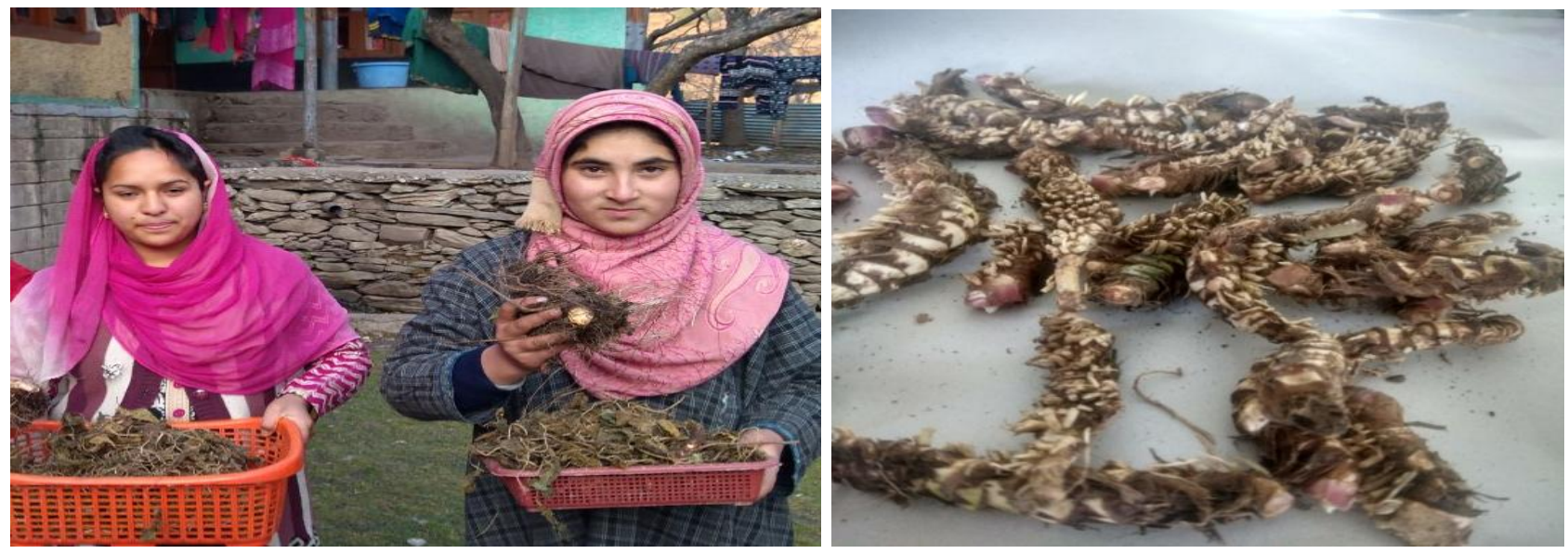

Also the average score of landholding was 1.45 which indicated the prevalence of marginal landholders among the sample households was more engaged in collection processes of the naturally growing herb. The data presented in the Table 8 revealed that 51.66 per cent of the respondents possessed livestock between 6 and 10 who were involved in this trade.

The mean score of main occupation was 3.15 indicating agriculture as the back bone of the economy in the areas. The cultivation remained the main occupation for 43.33 per cent of the respondents. The average score (2.43) indicated that the labour force among the sample households was substantial i.e. 3.

The results in the Table 9 illustrated that a considerable percentage $(53.33 \%)$ of the respondents belong to low income category, followed by very low income $(25.00 \%)$, medium income $(13.33 \%)$ and high income $(8.33 \%)$.

Also the average proximity to the wetlands among sample households was observed to be $1.94 \mathrm{~km}$. The mean score (1.96) of frequency of wetlands visits indicated that the people visit the wetland frequently (fortnightly/ monthly) in the study site. (Table) Extent of forest resource possession i.e. area owned under agro forestry/homestead forestry plantation was mostly ( $<0.10$ ha) among maximum $(50.00 \%)$ of the households followed by $0.11-0.20$ ha $(23.33 \%), 0.21-0.30$ ha $(16.66 \%)$ and $>0.30(10.00 \%)$. The average extent of agro forestry/homestead forestry plantation among the sample households was recorded to be 0.10 ha. The results were in conformation with the findings of Nida (2019) while studying the Ethnomedicinal practices and standardization of propagation techniques of Bergenia cilita L. in Kashmir, reported that the total average collection/annum of Bergenia ciliata was 75.4 $\mathrm{kg}$, the total average processing/annum was $69.5 \mathrm{~kg}$, the total average consumption/annum was $5.9 \mathrm{~kg}$, the total average sale/annum was $63.6 \mathrm{~kg}$, Umar (2017) while studying the Non-Timber Forest Products Supporting the Livelihood Security in Gurez Valley of Kashmir reported that NTFPs like fuel wood, fodder, edible fruit, vegetable, beverage, dye, oil seed, detergent, tooth brush and mouth freshener were mostly collected for household self-consumption whereas herbal medicine, spice, cottage industry materials, edible nut, fungi and Shilajeet were mainly collected for livelihood earning. The herbal medicine is the 
chief NTFPs marketed by about $88.34 \%$ of the households whereas; the involvement of households in marketing of Shilajeet was only $5.28 \%$. The herbal medicine fetched the maximum earning (Rs.756400/annum) while incense accrued lowest income of Rs.6400/ annum only in the sample households. Giday et al., (2009) also found knowledge of ethnobotanical plant usage as they were more exposed to modern medicine. But in case of areas devoid of modernization such difference does not exist. The positive and significant relationship of family composition with the extraction of forest carbon could be attributed to the fact that the larger sized families were having more labour force available for more extraction of forest resources (Egeru et al., 2010; Larinde et al., 2011).

In conclusion the livelihood security from Acorus calamus depends on multitude of household socioeconomic and biophysical characteristics like education, size of family, size of land holding, herd size, main occupation, family labour, gross annual income, proximity to wetlands, frequency of wetland visit and forest resource possession.The study concludes that of the all off-farm and on-farm income sources agriculture contributed maximum income followed by livestock, herbal medicine, service, Acorus based cottage industry, business, wage labour and others. Likewise, among the employment sources Agriculture generated maximum employment opportunities followed by livestock, herbal medicine, service, Acorus based cottage industry, business, wage labour and others. Hence, the Acorus based cottage industry is the $5^{\text {th }}$ major component of household economy and employment.

\section{References}

Bharathkumar, L.B., Patil, B.L., Basavaraja, H., Mundinamani, S.M.,
Mahajanashetty, S.B. and Megeri, S.N. 2011. Participation behaviour of indigenous people in non-timber forest products extraction in Western Ghats forests. Karnataka Journal of Agricultural Sciences. 24(2): 170-172.

Divya, G., Gajalakshmi, S., Mythili, S. and Sathiavelu, A. 2011. Pharmacological Activities of Acorus calamus: A review. Asian Journal Biochemical Pharmacy Resources 1: 57-64

Giday, M., Asfaw, Z., Woldu, Z. and Teklehaymanot, T. 2009. Medicinal plant knowledge of the Bench ethnic group of Ethiopia: an ethnobotanical investigation, Journal of Ethnobiology and Ethnomedicine 5: 34-43.

Egeru, A., Majaliwa, J. G. M., Isubukalu, P. S., Mukwaya, P. and Katerega, E. 2010. The determinants of fuel wood demand. A case of Olio Sub-country eastern Uganda. In: second RUFORUM Biennial Meeting pp. 1593-98

Ibrahim. A.O., Ampitan, T.A., Adeniji, O.A., Olayinka, A.P. and Babatunde, K.O. 2016. Utilization of Non-Timber Forest Products (NTFPs) in New Bussa, Nigeria. International Journal of Research in Agriculture and Forestry, 3(10): 34-43.

Larinde, S. L. and Olasupo, O. 2011. Socioeconomic importance of fuel wood production in Gambani forest reserve area, Nigeria. Agriculture and Social Research 11(1): 201-210.

Nida, R. 2018. Ethno medicinal practices and standardization of propagation techniques of Bergenia ciliata L., in Kashmir. M. Sc. thesis submitted to Faculty of Forestry, Sher-e-Kashmir University of Agricultural Science \& Technology of Kashmir, Shalimar.

Pandey, A.K., Tripathi, Y.C. and Kumar, A. 2016. Non timber forest (NTFPs) for sustained livelihood challenges and 
strategies. Research journal of forestry, 6(2): 23-33.

Sapkota, I.P. and Odén, P.C. 2008 Household Characteristics and Dependency on Community Forests in Terai of Nepal. International Journal of Social Forestry, 1(2): 123-144.

Shillington, L.J. 2002. Non-timber forest products, gender and households in Nicaragua: a community chain analysis. M.Sc. thesis submitted to Virginia Polytechnic Institute, Blacksburg, Virginia

Ummar, A. 2017. Non-Timber Forest Products Supporting the Livelihood Security in Gurez Valley of Kashmir. M. Sc. thesis submitted to Faculty of Forestry, Sher-e-Kashmir University of Agricultural Sciences \& Technology of Kashmir, Shalimar.

Qazi, G. N. 2003. Resources, technologies and knowledge-sharing on medicinal and aromatic plants from India. In: Workshop on Strengthening Cooperation of MAPs National Focal Points, ICS-UNIDO, Trieste, Italy pp. 26-27.

Venkataramaiah P. Development of socioeconomic status scale, Ph.D. Thesis, Department of Agricultural Extension, University of Agriculture Sciences, Bangalore; 1990.

World Bank, 2001. A revised forest strategy for the World Bank group. Washington, DC.

\section{How to cite this article:}

Bhat, G. M., Rayees A. Bhat, M. A. Islam, T. A. Rather, F. A. Shahkhan, Huzaifa Majeed and Nida Rafiq. 2020. Importance of Acorus calamus in Rural Livelihood Security of District Ganderbal in Kashmir Valley, India. Int.J.Curr.Microbiol.App.Sci. 9(10): 986-994. doi: https://doi.org/10.20546/ijcmas.2020.910.118 